\title{
Probiotic Potentiality from Versatile Lactiplantibacillus plantarum Strains as Resource to Enhance Freshwater Fish Health
}

\author{
Massimo Iorizzo (D), Gianluca Albanese (D), Francesco Letizia *, Bruno Testa (D), Patrizio Tremonte, Franca Vergalito, \\ Silvia Jane Lombardi, Mariantonietta Succi, Raffaele Coppola (D) and Elena Sorrentino *(D)
}

Citation: Iorizzo, M.; Albanese, G.; Letizia, F.; Testa, B.; Tremonte, P.;

Vergalito, F.; Lombardi, S.J.; Succi, M.; Coppola, R.; Sorrentino, E. Probiotic Potentiality from Versatile Lactiplantibacillus plantarum Strains as Resource to Enhance Freshwater Fish Health. Microorganisms 2022, 10, 463. https://doi.org/10.3390/ microorganisms10020463

Academic Editor: Jorge Barros-Velázquez

Received: 13 January 2022

Accepted: 15 February 2022

Published: 17 February 2022

Publisher's Note: MDPI stays neutral with regard to jurisdictional claims in published maps and institutional affiliations.

Copyright: (C) 2022 by the authors. Licensee MDPI, Basel, Switzerland. This article is an open access article distributed under the terms and conditions of the Creative Commons Attribution (CC BY) license (https:// creativecommons.org/licenses/by/ $4.0 /)$.
Department of Agricultural, Environmental and Food Sciences, University of Molise, 86100 Campobasso, Italy; iorizzo@unimol.it (M.I.); g.albanese@studenti.unimol.it (G.A.); bruno.testa@unimol.it (B.T.); tremonte@unimol.it (P.T.); franca.vergalito@unimol.it (F.V.); silvia.lombardi@unimol.it (S.J.L.); succi@unimol.it (M.S.); coppola@unimol.it (R.C.)

* Correspondence: f.letizia@studenti.unimol.it (F.L.); sorrentino@unimol.it (E.S.)

\begin{abstract}
Dietary probiotic supplementation has the potential to enhance the health of fish and their disease resistance. In this study, some properties of ten Lactiplantibacillus plantarum strains have been evaluated, for their potential use as probiotics in freshwater fish diet. In particular, antimicrobial activity, antioxidant activity, the potentiality to survive the gastrointestinal transit and persist in the intestine, were evaluated in vitro. The experimental tests were carried out at $15{ }^{\circ} \mathrm{C}$ and $30{ }^{\circ} \mathrm{C}$ to determine the suitability of these lactic acid bacteria to be used as probiotics in the diet of fish grown at different temperatures. The results demonstrated that the evaluated Lp. plantarum strains, which often have significant differences among themselves, are characterized by important functional characteristics such as cell surface properties (auto-aggregation and hydrophobicity), ability to produce antioxidant substances, capacity to survive in the presence of $0.3 \%$ bile salts and acidic environment $(2.5 \mathrm{pH})$, antagonistic activity against some fish opportunistic pathogens (A. salmonicida, Ps. aeruginosa, E. coli and C. freundii) and other unwanted bacteria present in fish products (S. aureus and L. innocua). The outcomes suggest that these Lp. plantarum strains may be candidates as probiotics in warm- and cold-water aquaculture.
\end{abstract}

Keywords: aquaculture; probiotic; Lactiplantibacillus plantarum; fish health

\section{Introduction}

Aquaculture has become an important economic activity in many countries [1]. The current intensification of aquaculture has led to the promotion of conditions that favor the development of infection and disease-related problems [2]. Bacterial diseases in fish farming can cause high mortality, with subsequent economic losses [3]. The conventional approach so far applied in the mitigation, or cure, of bacterial diseases has been mainly based on the use of antibiotics [4].

The misuse of these compounds, however, is known to have several ancillary complications, such as negative effects on the gut microbiota $[5,6]$ and antibiotic accumulation in edible products [7-9]. In addition, there is a general concern over the increased numbers of antibiotic-resistant bacteria in the environment $[10,11]$.

As such, there is a growing concern to have other safe, non-antibiotic-based and eco-friendly alternatives for the treatment of the diseases [12]. In response to the reduction in antibiotic use in fish farming, vaccination has been playing a pivotal role in the control of infectious diseases in aquaculture for decades [13]. The wide acceptance of vaccines stems from the fact that there is no risk of drug resistance development in vaccinated animals and for the resulting protection of unvaccinated animals due to herd immunity. Conversely, the role of every vaccine is limited to the control and prevention of a single infectious disease [14]. Subsequently, a single approach is not sufficient to maintain the health status of fish in aquaculture, but rather a combination of different strategies is required. 
In recent years, the use of probiotics as agents of biological control is a promising alternative approach for the control of infectious agents and treatment of diseases $[15,16]$. Although probiotics were initially used for disease control, their use in aquaculture has now extended for further reasons: improvement of fish growth and reproduction, enzymatic contribution to digestion, modulation of the gut microbiota, enhancement of hematological parameters and immune response [15-19]. Lactic acid bacteria (LAB) have gained considerable attention as probiotics in aquaculture, and over the last two decades, numerous investigations were carried out to evaluate the probiotic properties of different genera and species [20-23]. Based on these studies, it is evident that LABs along with other bacteria that belong to the indigenous microbiota play an important role in improving the health and welfare of fish. Among several probiotic bacterial species, several reports have been published on the beneficial role of Lactiplantibacillus plantarum (previously Lactobacillus plantarum) and its use as a probiotic in aquaculture [24-27]. Lp. plantarum is a bacterium capable of colonizing several ecological niches, including the intestinal tract of mammals, insects, and fishes [28-30]. Many studies have shown that some Lp. plantarum strains that inhabit our intestinal tract must have intrinsic resistance mechanisms to resist the gastrointestinal transit $[31,32]$. Recently, several studies have suggested that $L p$. plantarum is a versatile $\mathrm{LAB}$, among the most important due to its distinctive probiotic properties, as it can tolerate acid and bile conditions as well as exhibit antioxidant and antimicrobial activities [33-39]. Therefore, some strains of $L p$. plantarum are proposed or used as probiotics in aquaculture practices [40-42]. Considering the positive impact of probiotics, it is important to select new specific strains to be used in freshwater fish aquaculture [20,43].

This study focused on some functional and probiotic activities of ten Lp. plantarum strains, to assess their suitability to be used as probiotics in aquaculture. In particular, antioxidant and antimicrobial activities, cell surface properties (auto-aggregation and hydrophobicity) and capability to survive at low $\mathrm{pH}$ and in the presence of bile salts were studied. Our tests were conducted at temperatures of $15^{\circ} \mathrm{C}$ and $30^{\circ} \mathrm{C}$ degrees.

The reason for this experimental choice was to evaluate the versatility of the selected Lp. plantarum strains and their possible use as probiotics in the diet of farmed fish grown at different temperatures.

\section{Materials and Methods}

\subsection{LAB Strains}

Ten $L p$. plantarum strains $(23 \mathrm{~V}, 33 \mathrm{~V}, 36 \mathrm{~V}, 37 \mathrm{~V}, 64 \mathrm{~V}, 65 \mathrm{~V}, 66 \mathrm{~V}, 67 \mathrm{~V}, 68 \mathrm{~V}, 73 \mathrm{~V})$ isolated from the intestinal tract of the Mediterranean trout (Salmo macrostigma) were used [30]. Their 16S rRNA sequences have been deposited in GenBank under accession numbers from MZ452092 to MZ452095 and from MZ452098 to MZ452103.

\subsection{Antimicrobial Activity}

The antimicrobial activity of the Lp. plantarum strains (producers) was evaluated against the following indicator bacteria: Escherichia coli ATCC 11775, Listeria innocua ATCC 33090, Proteus mirabilis ATCC 29906, Staphylococcus aureus ATCC 29213, Pseudomonas aeruginosa ATCC 27853, Citrobacter freundii ATCC 8090, and Aeromonas salmonicida ATCC 33658 belonging to the American Type Culture Collection (ATCC Manassas, VA, USA).

The L $p$. plantarum strains were grown in MRS broth (Oxoid Ltd., Hampshire, UK). After $16 \mathrm{~h}$ at $30^{\circ} \mathrm{C}$, the broth culture of every single strain was centrifugated $(8000 \times g \mathrm{rpm}$ for $10 \mathrm{~min}$ at $4{ }^{\circ} \mathrm{C}$ ) to separate the cell pellet from the cell-free supernatant (CFS). Before being used, the CFS was mechanically sterilized by means of filtration (cellulose acetate membrane, pore size $0.22 \mu \mathrm{m}$ (Sigma-Aldrich; St. Louis, M0, USA).

The antimicrobial activity of CFSs were tested in accordance with the Kaewchomphunuch et al. protocol [44]. As a negative control, $50 \mu \mathrm{L}$ of MRS, adjusted to $\mathrm{pH} 3.8$ with hydrochloric acid $1 \mathrm{~N}$ (Sigma-Aldrich), was used. Antibacterial activity has been evaluated after $72 \mathrm{~h}$, at $15^{\circ} \mathrm{C}$ and $30^{\circ} \mathrm{C}$, measuring the diameter $(\mathrm{mm})$ of the clear zone of inhibition (ZOI) around the inoculated wells [44]. The tests were conducted in triplicate. 


\subsection{Evaluation of Acid and Bile Tolerance}

The Lp. plantarum strains were anaerobically grown in MRS for $18 \mathrm{~h}$ at $30^{\circ} \mathrm{C}$. The cells were collected by centrifugation, washed twice with physiological solution $(\mathrm{NaCl} 0.9 \%)$, and suspended in MRS broth. In order to assess the ability of bacteria to survive acidic environments, $100 \mu \mathrm{L}$ of bacterial suspension were transferred in test tubes containing $10 \mathrm{~mL}$ of MRS adjusted to $\mathrm{pH} 2.5$ with $1 \mathrm{M} \mathrm{HCl}$ (Sigma-Aldrich; St. Louis, MO, USA). Similarly, to determine the bile tolerance, $100 \mu \mathrm{L}$ of bacterial suspension were transferred in test tubes containing $10 \mathrm{~mL}$ of MRS enriched with $0.3 \%(w / v)$ of bile salts (cholic acid sodium salt, 50\%; deoxycholic acid sodium salt, 50\% Sigma-Aldrich) [44].

Finally, the test tubes were incubated at $15^{\circ} \mathrm{C}$ and $30{ }^{\circ} \mathrm{C}$ in anaerobiosis. Viable cell counts were performed at the beginning of the trial and after 3 and $24 \mathrm{~h}$ by plate counting on MRS agar incubated anaerobically at $30^{\circ} \mathrm{C}$ for $48 \mathrm{~h}$. The experiments were performed in triplicate and expressed as mean values.

\subsection{Cell Surface Properties}

\subsubsection{Bacterial Cultures}

The bacterial strains were grown in MRS broth at $30^{\circ} \mathrm{C}$. After $12 \mathrm{~h}$, the cultures were centrifugated $\left(8000 \times \mathrm{g} \mathrm{rpm}\right.$ for $15 \mathrm{~min}$ at $\left.4{ }^{\circ} \mathrm{C}\right)$, washed twice and resuspended in a sterile phosphate buffer saline (PBS, pH 7) to an optical density of 0.5 MacFarland scale $\left(\mathrm{OD}_{580}\right)$ to standardize the bacterial density at $10^{8} \mathrm{CFU} / \mathrm{mL}$ [45]. The $\mathrm{OD}_{580}$ of bacterial suspension (BS) was measured using a spectrophotometer (Multilabel Counter-PerkinElmer 1420, San Jose, CA, USA). The tests were then conducted in triplicate.

\subsubsection{Auto-Aggregation}

The auto-aggregation (AA) assay was performed according to Iorizzo et al. [31]. The absorbance measurements $\left(\mathrm{OD}_{580}\right)$ of the BSs were carried out after $1,2,5$, and $24 \mathrm{~h}$ at $15^{\circ} \mathrm{C}$ and $30{ }^{\circ} \mathrm{C}$. The AA (\%) was obtained using the following formula: $\mathrm{AA} \%=\left(1-\mathrm{OD}_{\mathrm{t}} / \mathrm{OD}_{0}\right)$ $\times 100$ [46], where $\mathrm{OD}_{0}$ is the initial absorbance and $\mathrm{OD}_{\mathrm{t}}$ is the absorbance detected after 1 , 2,5 , and $24 \mathrm{~h}$.

\subsubsection{Hydrophobicity}

The percentage hydrophobicity has been determined considering the capacity of Lp. plantarum strains to adhere to hydrocarbons (BATH) using xylene and toluene [47]. The BS was added with $50 \%$ of every single hydrocarbon and the two-phase system was vortexed for $5 \mathrm{~min}$. After 15,30 , and $60 \mathrm{~min}$ of stationary phase at $15^{\circ} \mathrm{C}$ and $30^{\circ} \mathrm{C}$, the aqueous phase was carefully removed and spectrophotometric readings were carried out using the wavelength control set to $580 \mathrm{~nm}$. Hydrophobicity $(\mathrm{H})$ was calculated as a percentage decrease in optical density and was expressed using the following formula: $\left.\mathrm{H} \%=\left(1-\mathrm{OD}_{\mathrm{t}} / \mathrm{OD}_{0}\right) \times 100\right)[46]$, where $\mathrm{OD}_{\mathrm{t}}$ represents the absorbance after 15,30 , and $60 \mathrm{~min}$, while $\mathrm{OD}_{0}$ represents the optical density value before adding the hydrocarbon.

\subsection{Antioxidant Activity}

The overnight cultures $\left(10^{7} \mathrm{CFU} / \mathrm{mL}\right)$ of the Lp. plantarum strains in $10 \mathrm{~mL}$ of MRS medium were centrifuged at $8000 \times \mathrm{g}$ rpm for $5 \mathrm{~min}$ at $4{ }^{\circ} \mathrm{C}$.

Cell pellets $(\mathrm{CP})$ were fractionated into two aliquots for the protein contents and antioxidant activity. Total cell protein extraction was carried out resuspending the $\mathrm{CP}$ in $1 \mathrm{~mL}$ of $\mathrm{NaOH} 0.1 \mathrm{M}$, treated with heat at $95^{\circ} \mathrm{C}$ for $20 \mathrm{~min}$ and stored at $4{ }^{\circ} \mathrm{C}$. After $24 \mathrm{~h}$, samples were centrifugated at $13,000 \times \mathrm{g} \mathrm{rpm}$ for $15 \mathrm{~min}$ at $4{ }^{\circ} \mathrm{C}$ and the supernatants were used for protein quantification according to Di Martino et al. [48]. The cell protein was expressed as $\mathrm{mg} / \mathrm{mL}$, using bovine serum albumin (BSA) as the standard.

For the antioxidant activity, the cell pellet was washed twice with sterile water and resuspended in $500 \mu \mathrm{L}$ of cold pure methanol, and after $12 \mathrm{~h}$ of storage at $-20^{\circ} \mathrm{C}$, centrifuged at $13,000 \times \mathrm{g} \mathrm{rpm}$ for $15 \mathrm{~min}$ at $4{ }^{\circ} \mathrm{C}$. The supernatants of cell extract (CES) were used for the evaluation of the antioxidant activity. 
Antioxidant activity of the CES was evaluated using the 2,2 azino-bis 3ethylbenzothiazoline-6-sulfonic acid (ABTS-+) radical cation method according to Re et al. [49] and scavenging of 2,2-diphenyl-1-picrylhydrazyl (DPPH) free radical according to the method described by Aarti et al. [50], with some modifications. ABTS radical cations (ABTS + ) were produced by reacting the ABTS methanol solution $7 \mathrm{mM}$ with $2.45 \mathrm{mM}$ potassium persulfate, storing it in the dark at room temperature for $24 \mathrm{~h}$ before use. The ABTS + solution was diluted with cold pure methanol to an optical density (OD) of 0.700 at $745 \mathrm{~nm}$. Then, $100 \mu \mathrm{L}$ of CES were mixed with $900 \mu \mathrm{L}$ of the ABTS + solution. The OD was measured at $745 \mathrm{~nm}$ after $6 \mathrm{~min}$ in the dark at room temperature using a BioSpectrometer (Eppendorf).

For the DPPH radical-scavenging capacity, $100 \mu \mathrm{L}$ of CES were mixed with $900 \mu \mathrm{L}$ of DPPH radical solution $(0.05 \mathrm{mM})$ and diluted with cold pure methanol to OD of 0.700 at $515 \mathrm{~nm}$ after $15 \mathrm{~min}$.

For ABTS and DPPH assays, Trolox was used as the standard for the calibration curve.

The antioxidant activity was expressed as the ratio $(w / w)$ between $\mu \mathrm{g} / \mathrm{mL}$ Trolox and $\mathrm{mg} / \mathrm{mL}$ of total cell protein (BSA equivalents). All the reagents used for this experiment were from Sigma-Aldrich.

\subsection{Statistical Analysis}

All the data obtained from the three independent experiments are expressed as mean \pm standard deviation (SD). Statistical analysis was performed using an analysis of variance (ANOVA) followed by Tukey's multiple comparison test. Statistical significance was attributed to $p$-values $<0.05$ using SPSS software (IBM SPSS Statistics 21) for the analysis.

\section{Results}

\subsection{Antimicrobial Activity}

The results of the antagonistic activity of the $\mathrm{Lp}$. plantarum strains against indicator bacteria at $15{ }^{\circ} \mathrm{C}$ and $30^{\circ} \mathrm{C}$ are presented in Tables 1 and 2 as the mean diameter (mm) of the growth inhibition zone (ZOI). Tests using the acidified MRS pH 3.8 showed no inhibitory effect. At $30^{\circ} \mathrm{C}$, all the CFSs of the Lp. plantarum strains inhibited the growth of indicator bacteria causing ZOI between 5 and $14 \mathrm{~mm}$, in some cases with statistically significant differences. At $15^{\circ} \mathrm{C}$, the overall results show there was a greater diversification of antagonistic activity than that caused at $30^{\circ} \mathrm{C}$. The results of the antimicrobial activity conducted at $30^{\circ} \mathrm{C}$ showed the ability of the ten Lp. plantarum to inhibit all indicator strains. The specific data at $15{ }^{\circ} \mathrm{C}$ showed an inhibitory effect of all tested Lp. plantarum strains against $A$. salmonicida, Ps. aeruginosa, E. coli, and C. freundii, while only L p. plantarum $66 \mathrm{~V}$, $67 \mathrm{~V}, 68 \mathrm{~V}$, and $73 \mathrm{~V}$ were able to partially inhibit the development of S. aureus and L. innocua.

\section{2. $p H$ and Bile Resistance}

To survive and persist in the gastrointestinal tract, probiotic candidates must be able to survive in an acidic environment and in the presence of bile salts. The results of the effect of acid and bile stress on the survival of the Lp. plantarum strains are reported in Tables S1 and S2 (Supplementary Materials). All the examined strains exhibited high resistance in an acidic environment $(\mathrm{pH} 2.5)$ and the presence of bile salts $(0.3 \%)$ with significant differences between them.

The viability of lactobacilli, in MRS at $\mathrm{pH} 2.5$ after $2 \mathrm{~h}$ of incubation, from the initial number of $8.00 \log \mathrm{CFU} / \mathrm{mL}$ decreases approximately only $1 \log$ cycle at $15^{\circ} \mathrm{C}$ and $30^{\circ} \mathrm{C}$. The general comparison of all strains examined, for significant differences in the cell viability, indicated similar $\mathrm{pH}$ tolerance. The bile salts present in bacterial cultures were much less effective on bacterial viability than the effect of $\mathrm{pH} 2.5$. The selected $\mathrm{Lp}$. plantarum strains were able to survive in the presence of $0.3 \%$ bile salts. In fact, over $24 \mathrm{~h}$, they maintained almost entirely the initial viability $(8 \log \mathrm{CFU} / \mathrm{mL})$ both at $15^{\circ} \mathrm{C}$ and at $30^{\circ} \mathrm{C}$. 
Table 1. Antimicrobial activity at $15^{\circ} \mathrm{C}$ by cell-free supernatant (CFS) of the tested Lp. plantarum strains against different indicator bacteria. The data (mean $\pm \mathrm{SD} ; n=3$ ) are expressed as zone of inhibition-ZOI (mm). Different lowercase letters $(\mathrm{a}-\mathrm{d})$ in each row indicate significant differences $(p<0.05)$.

\begin{tabular}{|c|c|c|c|c|c|c|c|c|c|c|}
\hline \multirow{2}{*}{$\begin{array}{c}\text { Indicator } \\
\text { Strains }\end{array}$} & \multicolumn{10}{|c|}{ Lp. plantarum Strains } \\
\hline & $23 \mathrm{~V}$ & $33 \mathrm{~V}$ & $36 \mathrm{~V}$ & $37 \mathrm{~V}$ & $64 \mathrm{~V}$ & $65 \mathrm{~V}$ & $66 \mathrm{~V}$ & $67 \mathrm{~V}$ & $68 \mathrm{~V}$ & $73 \mathrm{~V}$ \\
\hline L. innocua & $0 \pm 0^{d}$ & $0 \pm 0^{\mathrm{d}}$ & $0 \pm 0^{\mathrm{d}}$ & $0 \pm 0^{\mathrm{d}}$ & $0 \pm 0^{d}$ & $0 \pm 0^{d}$ & $7.1 \pm 0.2^{a}$ & $5.0 \pm 0.3^{c}$ & $5.5 \pm 0.4^{b}$ & $5.9 \pm 0.5^{b}$ \\
\hline A. salmonicida & $7.0 \pm 0.6^{b}$ & $7.0 \pm 0.5^{b}$ & $7.7 \pm 0.6^{\mathrm{a}}$ & $7.5 \pm 0.6^{\mathrm{a}}$ & $8.5 \pm 0.3^{\mathrm{a}}$ & $7.3 \pm 0.3^{\mathrm{a}}$ & $6.6 \pm 0.6^{b}$ & $7.5 \pm 0.3^{\mathrm{a}}$ & $8.0 \pm 0.2^{\mathrm{a}}$ & $7.7 \pm 0.6^{\mathrm{a}}$ \\
\hline C. freundii & $7.2 \pm 0.7^{c}$ & $7.2 \pm 0.6^{c}$ & $8.0 \pm 0.4^{b}$ & $6.4 \pm 0.6^{c}$ & $9.9 \pm 0.4^{\mathrm{a}}$ & $7.0 \pm 0.4^{c}$ & $10.5 \pm 0.4^{\mathrm{a}}$ & $9.0 \pm 0.6^{\mathrm{b}}$ & $10.2 \pm 0.3^{a}$ & $10.3 \pm 0.5^{\mathrm{a}}$ \\
\hline P. mirabilis & $9.2 \pm 0.6^{\mathrm{a}}$ & $7.4 \pm 0.6^{b}$ & $8.3 \pm 0.5^{b}$ & $9.7 \pm 0.4^{\mathrm{a}}$ & $9.5 \pm 0.5^{\mathrm{a}}$ & $9.0 \pm 0.2^{\mathrm{a}}$ & $9.6 \pm 0.4^{\mathrm{a}}$ & $10.1 \pm 0.2^{\mathrm{a}}$ & $9.5 \pm 0.4^{\mathrm{a}}$ & $7.3 \pm 0.6^{b}$ \\
\hline S. aureus & $0 \pm 0^{c}$ & $0 \pm 0^{c}$ & $0 \pm 0^{c}$ & $0 \pm 0^{c}$ & $0 \pm 0^{c}$ & $0 \pm 0^{\mathrm{c}}$ & $6.5 \pm 0.4^{b}$ & $7.1 \pm 0.5^{\mathrm{b}}$ & $8.9 \pm 0.3^{a}$ & $6.9 \pm 0.4^{b}$ \\
\hline Ps. aeruginosa & $7.0 \pm 0.3^{\mathrm{a}}$ & $8.0 \pm 0.3^{a}$ & $7.9 \pm 0.6^{a}$ & $8.0 \pm 0.7^{\mathrm{a}}$ & $7.9 \pm 0.6^{\mathrm{a}}$ & $6.8 \pm 0.3^{\mathrm{a}}$ & $6.0 \pm 0.1^{b}$ & $7.3 \pm 0.4^{\mathrm{a}}$ & $7.8 \pm 0.4^{\mathrm{a}}$ & $5.8 \pm 0.2^{b}$ \\
\hline E. coli & $8.8 \pm 0.6^{b}$ & $9.9 \pm 0.6^{\mathrm{a}}$ & $9.6 \pm 0.5^{a}$ & $10.1 \pm 0.1^{\mathrm{a}}$ & $9.8 \pm 0.2^{\mathrm{a}}$ & $6.9 \pm 0.4^{c}$ & $7.0 \pm 0.3^{c}$ & $7.8 \pm 0.3^{b}$ & $8.9 \pm 0.6^{a}$ & $7.1 \pm 0.1^{c}$ \\
\hline
\end{tabular}

Table 2. Antimicrobial activity at $30^{\circ} \mathrm{C}$ by cell-free supernatant (CFS) of the tested Lp. plantarum strains against different indicator bacteria. The data (mean $\pm \mathrm{SD} ; n=3$ ) are expressed as zone of inhibition-ZOI $(\mathrm{mm})$. Different lowercase letters $(\mathrm{a}-\mathrm{c})$ in each row indicate significant differences $(p<0.05)$.

\begin{tabular}{|c|c|c|c|c|c|c|c|c|c|c|}
\hline \multirow{2}{*}{$\begin{array}{c}\text { Indicator } \\
\text { Strains }\end{array}$} & \multicolumn{10}{|c|}{ Lp. plantarum Strains } \\
\hline & $23 \mathrm{~V}$ & $33 \mathrm{~V}$ & $36 \mathrm{~V}$ & $37 \mathrm{~V}$ & $64 \mathrm{~V}$ & $65 \mathrm{~V}$ & $66 \mathrm{~V}$ & $67 \mathrm{~V}$ & $68 \mathrm{~V}$ & $73 \mathrm{~V}$ \\
\hline L. innocua & $7.9 \pm 0.3^{b}$ & $7.9 \pm 0.2^{b}$ & $7.0 \pm 0.4^{c}$ & $8.0 \pm 0.3^{b}$ & $9.0 \pm 0.3^{\mathrm{a}}$ & $9.0 \pm 0.3^{a}$ & $5.9 \pm 0.4^{\mathrm{c}}$ & $10.0 \pm 0.5^{\mathrm{a}}$ & $8.2 \pm 0.8^{b}$ & $9.0 \pm 0.2^{\mathrm{a}}$ \\
\hline A. salmonicida & $7.8 \pm 0.6^{\mathrm{a}}$ & $8.2 \pm 0.6^{a}$ & $8.5 \pm 0.5^{\mathrm{a}}$ & $8.9 \pm 0.3^{a}$ & $8.4 \pm 0.5^{\mathrm{a}}$ & $7.2 \pm 0.8^{b}$ & $7.4 \pm 1.0^{\mathrm{a}}$ & $7.7 \pm 0.5^{\mathrm{a}}$ & $7.2 \pm 0.4^{\mathrm{b}}$ & $7.9 \pm 0.2^{a}$ \\
\hline C. freundii & $7.9 \pm 0.7^{b}$ & $8.7 \pm 0.8^{b}$ & $8.8 \pm 0.9^{b}$ & $9.8 \pm 1.2^{b}$ & $14.0 \pm 0.8^{\mathrm{a}}$ & $9.1 \pm 0.8^{b}$ & $7.9 \pm 0.3^{b}$ & $7.9 \pm 0.4^{b}$ & $8.9 \pm 0.6^{b}$ & $6.7 \pm 0.8^{\mathrm{c}}$ \\
\hline P. mirabilis & $7.0 \pm 0.5^{\mathrm{a}}$ & $8.0 \pm 0.3^{a}$ & $8.0 \pm 0.4^{a}$ & $7.1 \pm 0.6^{a}$ & $6.1 \pm 0.8^{b}$ & $6.9 \pm 0.6^{\mathrm{a}}$ & $5.2 \pm 0.5^{b}$ & $5.8 \pm 0.4^{b}$ & $6.4 \pm 0.5^{b}$ & $7.0 \pm 0.6^{a}$ \\
\hline S. aureus & $5.9 \pm 0.7^{b}$ & $5.9 \pm 0.6^{b}$ & $7.0 \pm 0.4^{\mathrm{a}}$ & $6.8 \pm 0.2^{a}$ & $6.8 \pm 0.6^{\mathrm{a}}$ & $6.7 \pm 0.2^{\mathrm{a}}$ & $7.0 \pm 0.6^{\mathrm{a}}$ & $7.9 \pm 0.6^{\mathrm{a}}$ & $7.2 \pm 0.4^{\mathrm{a}}$ & $6.2 \pm 0.6^{b}$ \\
\hline Ps. aeruginosa & $7.2 \pm 0.9^{\mathrm{a}}$ & $7.0 \pm 0.9^{a}$ & $6.4 \pm 0.5^{a}$ & $6.8 \pm 0.6^{a}$ & $6.9 \pm 0.5^{a}$ & $6.0 \pm 0.6^{\mathrm{a}}$ & $5.8 \pm 0.5^{a}$ & $7.4 \pm 0.4^{\mathrm{a}}$ & $7.0 \pm 0.3^{a}$ & $6.0 \pm 0.5^{\mathrm{a}}$ \\
\hline E. coli & $9.0 \pm 0.5^{\mathrm{a}}$ & $9.0 \pm 0.6^{\mathrm{a}}$ & $8.6 \pm 0.4^{\mathrm{a}}$ & $9.9 \pm 1.0^{\mathrm{a}}$ & $9.9 \pm 1.0^{\mathrm{a}}$ & $10.2 \pm 1.0^{\mathrm{a}}$ & $8.0 \pm 0.8^{b}$ & $7.9 \pm 0.5^{b}$ & $8.0 \pm 0.7^{b}$ & $7.0 \pm 0.6^{b}$ \\
\hline
\end{tabular}

\subsection{Cell Surface Properties: Hydrophobicity and Auto-Aggregation}

The hydrophobicity was investigated using the ability of the bacteria to adhere at $15{ }^{\circ} \mathrm{C}$ and $30{ }^{\circ} \mathrm{C}$ to toluene and xylene hydrocarbons. The hydrophobicity (\%) of the Lp. plantarum strains is reported graphically in Figure 1 and numerically in Table S3 (Supplementary Materials). In all tests, we have detected significant differences among the tested Lp. plantarum strains. For all strains, the adhesion to hydrocarbons increased gradually during the test period $(60 \mathrm{~min})$. Lp. plantarum $33 \mathrm{~V}$ and $67 \mathrm{~V}$ strains, already after 15 min both at $15^{\circ} \mathrm{C}$ and $30{ }^{\circ} \mathrm{C}$, showed a high adherence to toluene and xylene with a hydrophobicity percentage greater than $66 \%$, and after $60 \mathrm{~min}$, the percentage was greater than $90 \%$. After $60 \mathrm{~min}$ at $15^{\circ} \mathrm{C}, \mathrm{Lp}$. plantarum $23 \mathrm{~V}$ and $36 \mathrm{~V}$ adhered to toluene with a hydrophobicity percentage of $41.4 \%$ and $54 \%$, respectively, while for the other strains we found a hydrophobicity of less than $30 \%$. At $30{ }^{\circ} \mathrm{C}, \mathrm{Lp}$. plantarum $23 \mathrm{~V}$ and $36 \mathrm{~V}$ adhered to toluene with percentages of $49.5 \%$ and $67.5 \%$, respectively; the other strains did not show a percentage of hydrophobicity greater than $37 \%$. In the test with xylene after $60 \mathrm{~min}$, except for $\mathrm{Lp}$. plantarum 33V and 67V, the other strains did not exceed the hydrophobicity percentages obtained from Lp. plantarum $36 \mathrm{~V}: 49.5 \%$ at $30{ }^{\circ} \mathrm{C}$ and $48.1 \%$ at $15^{\circ} \mathrm{C}$.

The AA results are depicted in Figure 2, and the relative numeric data are presented in Table S4 (Supplementary Materials). The data highlighted significant differences among the tested L p plantarum strains. The tests showed that the ability to aggregate and sediment increased progressively, until reaching, after $24 \mathrm{~h}$, range values between $20 \%$ and $50 \%$ at $15^{\circ} \mathrm{C}$ and between $36 \%$ and $57 \%$ at $30{ }^{\circ} \mathrm{C}$. 
(A) Temperature $15{ }^{\circ} \mathrm{C}$
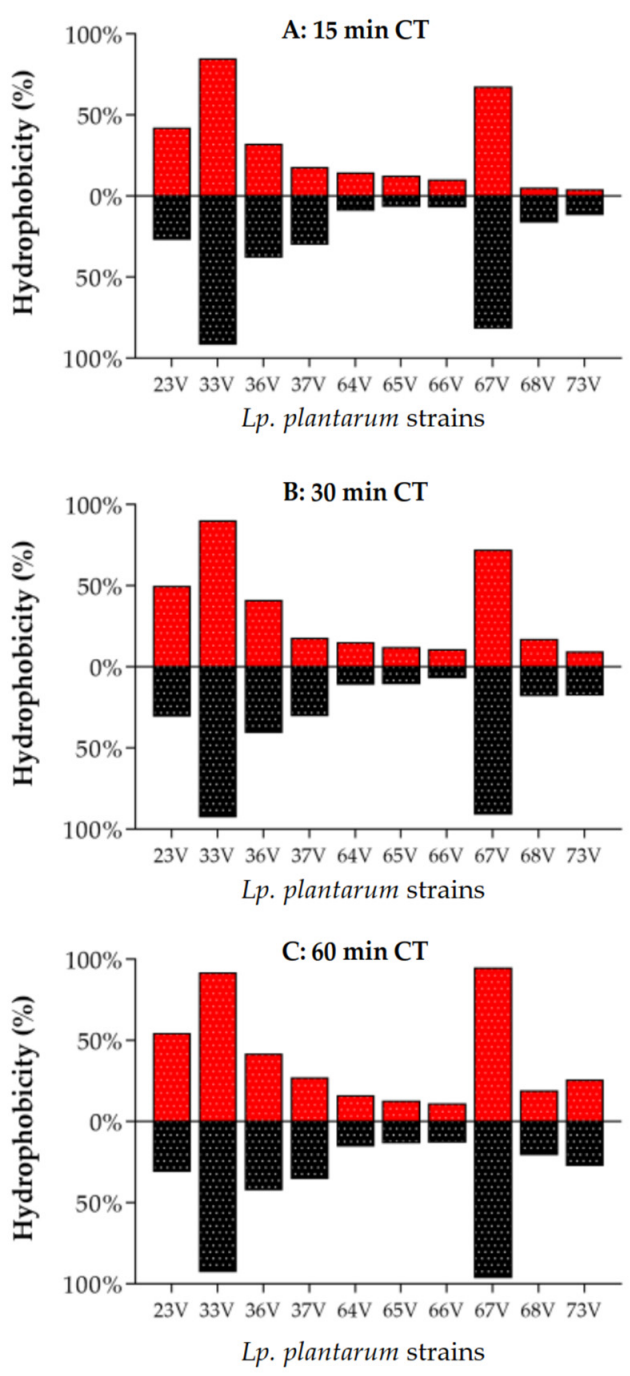

(B) Temperature $30^{\circ} \mathrm{C}$
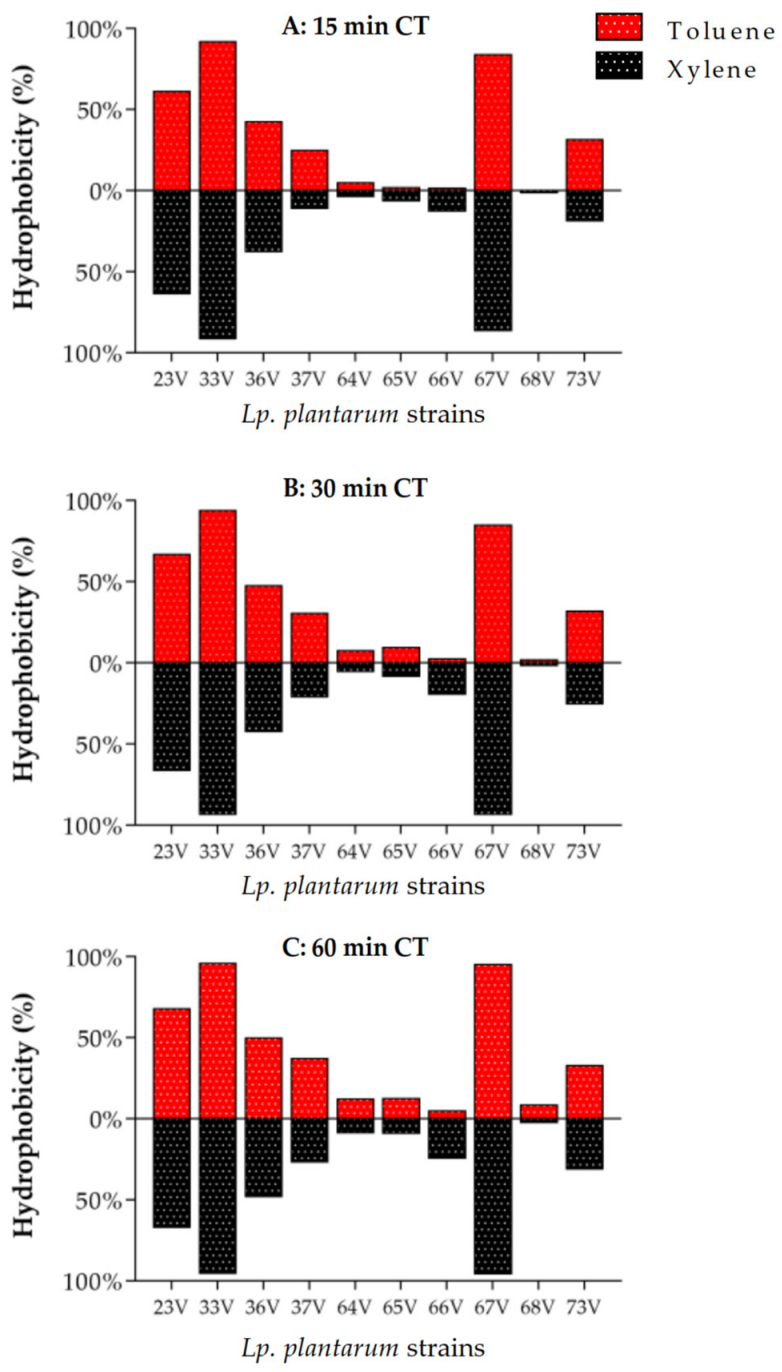

Figure 1. Adhesion of the Lp. plantarum strains to toluene and xylene expressed as hydrophobicity (\%) after 15,30 , and $60 \mathrm{~min}$ contact time $(\mathrm{CT})$ at $15{ }^{\circ} \mathrm{C}(\mathrm{A})$ and $30^{\circ} \mathrm{C}(\mathbf{B})$.

Lp. plantarum strains

Lp. plantarum strains
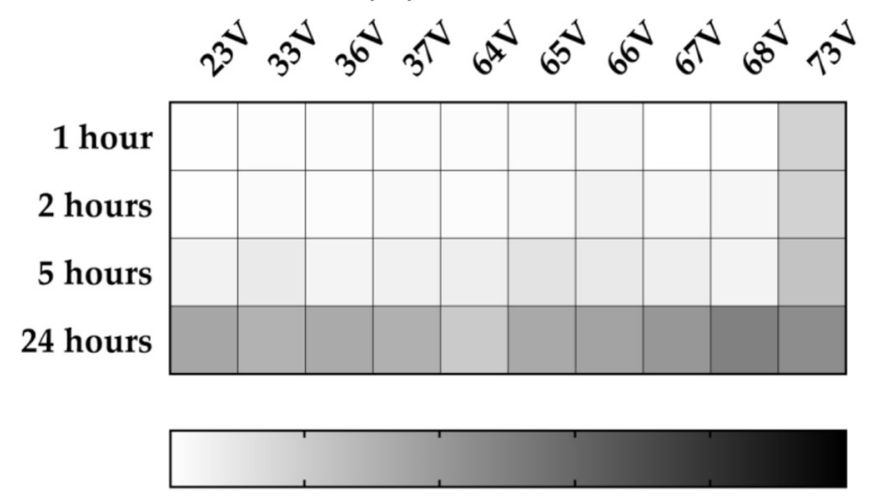

$20 \% \quad 40 \% \quad 60 \% \quad 80 \% \quad 100 \%$ Auto-aggregation (\%) A

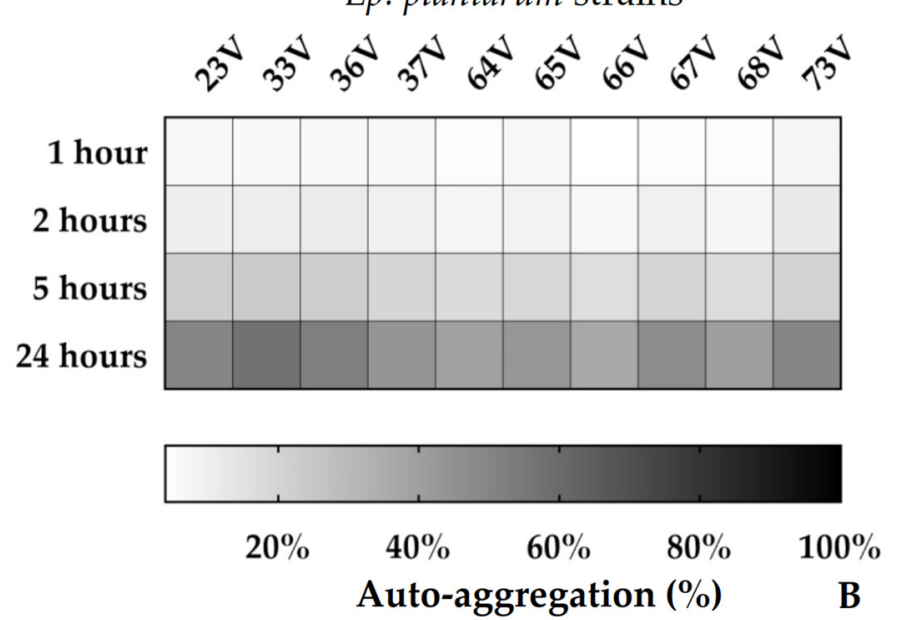

Figure 2. Auto-aggregation (AA\%) of the Lp. plantarum strains at $15^{\circ} \mathrm{C}(\mathbf{A})$ and $30{ }^{\circ} \mathrm{C}(\mathbf{B})$. 


\subsection{Antioxidant Activity}

The antioxidant activities, expressed as the ratio between $\mu \mathrm{g}$ Trolox $/ \mathrm{mL}$ and $\mathrm{mg} / \mathrm{mL}$ of cell protein (BSA equivalents), are shown in Table 3.

Table 3. Antioxidant activity of the Lp. plantarum strains. All values are expressed as mean \pm standard deviation $(n=3)$. Different lowercase letters $(a-d)$ in each row indicate significant differences $(p<0.05)$.

\begin{tabular}{|c|c|c|c|c|c|c|c|c|c|c|}
\hline \multirow{2}{*}{$\begin{array}{l}\text { Antioxidant } \\
\text { Assay }\end{array}$} & \multicolumn{10}{|c|}{ Lp. plantarum Strains } \\
\hline & $23 \mathrm{~V}$ & $33 \mathrm{~V}$ & $36 \mathrm{~V}$ & $37 \mathrm{~V}$ & $64 \mathrm{~V}$ & $65 \mathrm{~V}$ & $66 \mathrm{~V}$ & $67 \mathrm{~V}$ & $68 \mathrm{~V}$ & $73 \mathrm{~V}$ \\
\hline ABTS & $24.1 \pm 0.3^{\mathrm{d}}$ & $30.9 \pm 0.7^{b}$ & $31.5 \pm 1.1^{b}$ & $22.6 \pm 0.2^{d}$ & $31.0 \pm 1.1^{b}$ & $38.0 \pm 0.7^{\mathrm{a}}$ & $29.1 \pm 0.9^{b}$ & $31.2 \pm 1.4^{b}$ & $27.4 \pm 2.3^{c}$ & $25.9 \pm 0.6^{c}$ \\
\hline DPPH & $1.0 \pm 0.7^{b}$ & $1.3 \pm 0.3^{\mathrm{a}}$ & $1.6 \pm 0.1^{\mathrm{a}}$ & $0.8 \pm 0.4^{\mathrm{b}}$ & $1.3 \pm 0.1^{\mathrm{a}}$ & $1.5 \pm 0.6^{\mathrm{a}}$ & $1.0 \pm 0.4^{\mathrm{b}}$ & $2.2 \pm 0.1^{\mathrm{a}}$ & $2.1 \pm 0.3^{\mathrm{a}}$ & $1.2 \pm 0.1^{\mathrm{a}}$ \\
\hline
\end{tabular}

$\mu \mathrm{g}$ Trolox/mg cell proteins (BSA eq.)

The values obtained in ABTS assays were between 22.6 (37V strain) and 38.0 (65V strain), while the values obtained in DPPH assays were between 1.0 (23V strain) and 2.2 (67V strain).

\section{Discussion}

Fish's digestive tract is colonized by a wide microbial community that has important influences on the immune system, nutrient assimilation, and a wide range of other host activities. The gut microbiota can positively or negatively interact with each other. The interactions established among the components of the microbiota can significantly affect fish health. Fish become more susceptible to pathogens due to their stressful environment, which eventually suppresses their immune system, causing dysbiosis, which can lead to opportunistic infections that would be otherwise suppressed. Among all pathogens, bacteria are the most prominent disease-causing agents in fish and cause major problems and economic losses in commercial farming of a large number of cultivated fish species [51].

Conversely, an aggressive pathogen producing powerful virulence factors may be able to disrupt the normal microbial balance and lead to dysbiosis. Most surveys on probiotic applications in aquaculture consider the ability to inhibit pathogenic bacteria [52].

In this field, we evaluated the antagonistic activity of ten Lp. plantarum strains against some opportunistic fish pathogens (C. freundii, A. salmonicida, P. mirabilis, Ps. aeruginosa) and other unwanted bacteria present in fish products [6,53-56]. It is well known that some LAB strains may protect fish from intestinal pathogens by several possible mechanisms, including the production of inhibitory substances, such as organic acids, hydrogen peroxide, bacteriocins, and carbon peroxide [20,57].

Our results on the antimicrobial activity indicated that at 15 and $30^{\circ} \mathrm{C}$, the MRS $\mathrm{pH} 3.8$ did not inhibit the growth of indicator bacteria. The data obtained in our study seem to exclude that antibacterial activity is due to the acidic environment. Therefore, the antagonistic activity highlighted in our tests is probably due to substances produced by lactobacilli during the growth phase in the native CFS [58]. The nature of these substances needs to be investigated in the future. The ability to inhibit pathogens is a desirable property for probiotics and a sustainable alternative to antibiotics; dietary supplementation with these LABs may provide effective prophylaxis against infections in fish $[59,60]$. The fish, like other living organisms, developed an enzymatic antioxidant system including different enzymes (e.g., superoxide dismutase, glutathione peroxidase, glutathione reductase, and catalase) and a non-enzyme antioxidant system based on the production of different compounds as glutathione, thioredoxin, vitamin C, and vitamin E [61,62]. This complex system is capable of providing the balance between production and removal of reactive oxygen species (ROS) under normal physiological conditions. In fish, like other organisms, the lack of balance between the production of ROS and the antioxidant defense system can cause the oxidation of biological macromolecules, inducing cell damage [63]. Excessive production of ROS in fish can be caused by changes in environmental $\mathrm{O}_{2}$ (hyperoxia and hypoxia), temperature (hyper or hypothermia), and malnutrition [64]. In addition, the 
presence in the aquatic environment of heavy metals, pesticides (insecticides, herbicides, and fungicides), along with oil products, induces oxidative stress on fish [65]. In fact, various research studies proposed the use of new and safe natural antioxidants as an alternative for synthetic antioxidants [66]. Other studies in aquaculture have shown promising antioxidative effects of beneficial additives, such as probiotics, on different fish species $[67,68]$. Recently, LAB have been considered for their antioxidant activity $[66,68,69]$. Based on this evidence, in our research, we examined the antioxidant activity of selected L p . plantarum strains using the ABTS and DPPH methods. These two techniques may be utilized in aqueous and non-polar organic solvents to examine both hydrophilic and lipophilic antioxidants [70-73]. The obtained results showed that the selected Lp. plantarum strains possess antioxidant activity, confirming what has been reported in other studies conducted on this species [74-77].

The DPPH method provided lower values than the ABTS test. This difference is probably because it has a different sensitivity to the different antioxidant substances present in the CES, which needs to be investigated in further detail.

Consumption of probiotics alone, or foods supplemented with probiotics, may reduce oxidative damage in fish cells. The health-benefiting properties of probiotics are largely dependent on their prolonged residence in the GIT and are dictated by adherence to the intestinal mucosa. The ability of probiotic bacteria to adhere to intestinal epithelial cells involves various surface properties, including hydrophobicity and autoaggregation $[15,16,78]$. These characteristics promote the colonization and permanence of probiotics in the gastrointestinal tract (GIT). Moreover, the examined L p. plantarum strains had values of auto-aggregation and hydrophobicity in line with previous studies $[47,79]$. In particular, $L p$. plantarum $33 \mathrm{~V}$ and $67 \mathrm{~V}$ strains stood out for their performances. Our data confirm that some $\mathrm{Lp}$. plantarum strains have the potential to survive in the gastrointestinal tract and adhere to its epithelial cells $[80,81]$. An effective probiotic should be viable, safe, bile- and gastric-juices-tolerant, able to survive through the gastrointestinal tract, adhere and colonize gut epithelial cells. Our study showed a high survival of the 10 strains of Lp. plantarum in an acidic environment $(\mathrm{pH} 2.5)$ and the presence of $0.3 \%$ of bile salts. These results showed that some $\mathrm{Lp}$. plantarum strains had a high likelihood to survive stress in the gastrointestinal tract like low $\mathrm{pH}$ and bile presence, as highlighted in a previous study by Bucio et al. [82]. Gut transit time in fish depends on numerous factors including species, fish age/size, water temperature, food quality, meal size and feeding frequency [83,84]; water temperature influences gut transit time and nutrient digestibility as it can correlate to feed intake and enzyme activity $[85,86]$. This evidence motivated us to conduct bile tolerance tests for $24 \mathrm{~h}$. In addition, our tests were conducted at temperatures of $15^{\circ} \mathrm{C}$ and $30^{\circ} \mathrm{C}$ degrees. Fish are poikilotherms, they do not have a thermoregulatory system and their body temperature fluctuates in response to the temperature of the surrounding environment. Certain fish species are classified as cold-water fish, while others as warm-water or tropical fish; while cold-water fish are rarely exposed to temperatures greater than $20^{\circ} \mathrm{C}$, tropical fish are frequently exposed to temperatures well above $30^{\circ} \mathrm{C}$ [87].

Our results showed that the selected L $p$. plantarum strains have high adaptability to temperature, confirming the versatility of this species to adapt to different environmental conditions [88]. This characteristic would make it possible to use them in the diet of different fish species as well as make them tolerant to the different annual climatic seasons. The seasonal changes in water temperature can be extremely different for cold-water and warm-water species, they can range from below $5{ }^{\circ} \mathrm{C}$ to $19{ }^{\circ} \mathrm{C}$ and $16{ }^{\circ} \mathrm{C}$ to $39^{\circ} \mathrm{C}$, respectively $[89,90]$.

\section{Conclusions}

The supplementation of fish diet with specific probiotic microorganisms can contribute to improving the welfare and disease resistance, which is a widespread problem in aquaculture. The present study improves the application knowledge for the implementation of Lp. plantarum as probiotic in freshwater fish diet. Our results demonstrated that the 
examined $L p$. plantarum strains are characterized by important features such as antioxidant activity, ability to survive in the presence of bile, tolerance to low $\mathrm{pH}$, cell surface properties and antagonism activity against some fish pathogens. Therefore, these LABs meet some important criteria to be candidates as probiotics.

Supplementary Materials: The following supporting information can be downloaded at: https: //www.mdpi.com/article/10.3390/microorganisms10020463/s1, Table S1: Resistance to pH 2.5 at $15^{\circ} \mathrm{C}$ and $30{ }^{\circ} \mathrm{C}$, Table S2: Resistance to $0.3 \%$ bile salts at $15^{\circ} \mathrm{C}$ and $30{ }^{\circ} \mathrm{C}$, Table S3: Adhesion to toluene and xylene of $\mathrm{Lp}$. plantarum strains after different contact times; Table S4: Auto-aggregation (AA) at $15^{\circ} \mathrm{C}$ and $30^{\circ} \mathrm{C}$ of the Lp. plantarum strains.

Author Contributions: Conceptualization, M.I. and E.S.; data curation, G.A., F.L. and M.I.; formal analysis, F.V., G.A. and S.J.L.; funding acquisition, R.C. and M.S.; investigation, B.T. and P.T.; methodology, G.A. and B.T.; software, F.L. and B.T.; supervision, R.C. and E.S.; validation, P.T. and M.S.; writing-original draft, M.I.; writing-review and editing, M.I., G.A. and F.L. All authors have read and agreed to the published version of the manuscript.

Funding: This research received no external funding.

Institutional Review Board Statement: Not applicable.

Informed Consent Statement: Not applicable.

Data Availability Statement: The data presented in this study are available in the Supplementary Materials.

Conflicts of Interest: The authors declare no conflict of interest.

\section{References}

1. FAO. The State of World Fisheries and Aquaculture 2020. Sustainability in Action; FAO: Rome, Italy, 2020.

2. Rodger, H.D. Fish Disease Causing Economic Impact in Global Aquaculture. In Fish Vaccines; Adams, A., Ed.; Springer: Basel, Switzerland, 2016; pp. 1-34. ISBN 978-3-0348-0980-1.

3. Raja, R.A.; Jithendran, K.P. Aquaculture Disease Diagnosis and Health Management. In Advances in Marine and Brackishwater Aquaculture; Perumal, S., Thirunavukkarasu, A.R., Pachiappan, P., Eds.; Springer: New Delhi, India, 2015; pp. 247-255, ISBN 978-81-322-2271-2.

4. Sharma, M.; Pandey, G. Overviews of the Treatment and Control of Common Fish Diseases. Int. Res. J. Pharm. $2012,3,123-127$.

5. Romero, J.; Feijoó, C.G.; Navarrete, P. Antibiotics in Aquaculture-Use, Abuse and Alternatives. Health Environ. Aquac. 2012, 159.

6. Reith, M.E.; Singh, R.K.; Curtis, B.; Boyd, J.M.; Bouevitch, A.; Kimball, J.; Munholland, J.; Murphy, C.; Sarty, D.; Williams, J.; et al. The Genome of Aeromonas Salmonicida Subsp. Salmonicida A449: Insights into the Evolution of a Fish Pathogen. BMC Genom. 2008, 9, 427. [CrossRef] [PubMed]

7. Cabello, F.C. Heavy Use of Prophylactic Antibiotics in Aquaculture: A Growing Problem for Human and Animal Health and for the Environment. Environ. Microbiol. 2006, 8, 1137-1144. [CrossRef]

8. Okocha, R.C.; Olatoye, I.O.; Adedeji, O.B. Food Safety Impacts of Antimicrobial Use and Their Residues in Aquaculture. Public Health Rev. 2018, 39, 21. [CrossRef]

9. Lulijwa, R.; Rupia, E.J.; Alfaro, A.C. Antibiotic Use in Aquaculture, Policies and Regulation, Health and Environmental Risks: A Review of the Top 15 Major Producers. Rev. Aquac. 2020, 12, 640-663. [CrossRef]

10. Huang, Y.; Zhang, L.; Tiu, L.; Wang, H.H. Characterization of Antibiotic Resistance in Commensal Bacteria from an Aquaculture Ecosystem. Front. Microbiol. 2015, 6, 914. [CrossRef]

11. Kraemer, S.A.; Ramachandran, A.; Perron, G.G. Antibiotic Pollution in the Environment: From Microbial Ecology to Public Policy. Microorganisms 2019, 7, 180. [CrossRef]

12. Pérez-Sánchez, T.; Mora-Sánchez, B.; Balcázar, J.L. Biological Approaches for Disease Control in Aquaculture: Advantages, Limitations and Challenges. Trends Microbiol. 2018, 26, 896-903. [CrossRef]

13. Gudding, R.; Van Muiswinkel, W.B. A History of Fish Vaccination: Science-Based Disease Prevention in Aquaculture. Fish Shellfish Immunol. 2013, 35, 1683-1688. [CrossRef]

14. Assefa, A.; Abunna, F. Maintenance of Fish Health in Aquaculture: Review of Epidemiological Approaches for Prevention and Control of Infectious Disease of Fish. Vet. Med. Int. 2018, 2018, 5432497. [CrossRef] [PubMed]

15. Ringø, E. Probiotics in Shellfish Aquaculture. Aquac. Fish. 2020, 5, 1-27. [CrossRef]

16. Chauhan, A.; Singh, R. Probiotics in Aquaculture: A Promising Emerging Alternative Approach. Symbiosis 2019, 77, 99-113. [CrossRef] 
17. Merrifield, D.; Bradley, G.; Baker, R.; Davies, S. Probiotic Applications for Rainbow Trout (Oncorhynchus Mykiss Walbaum) II. Effects on Growth Performance, Feed Utilization, Intestinal Microbiota and Related Health Criteria Postantibiotic Treatment. Aquac. Nutr. 2010, 16, 496-503. [CrossRef]

18. Akhter, N.; Wu, B.; Memon, A.M.; Mohsin, M. Probiotics and Prebiotics Associated with Aquaculture: A Review. Fish Shellfish Immunol. 2015, 45, 733-741. [CrossRef]

19. Hoseinifar, S.H.; Sun, Y.-Z.; Wang, A.; Zhou, Z. Probiotics as Means of Diseases Control in Aquaculture, a Review of Current Knowledge and Future Perspectives. Front. Microbiol. 2018, 9, 2429. [CrossRef]

20. Ringø, E.; Van Doan, H.; Lee, S.H.; Soltani, M.; Hoseinifar, S.H.; Harikrishnan, R.; Song, S.K. Probiotics, Lactic Acid Bacteria and Bacilli: Interesting Supplementation for Aquaculture. J. Appl. Microbiol. 2020, 129, 116-136. [CrossRef]

21. Merrifield, D.L.; Carnevali, O. Probiotic Modulation of the Gut Microbiota of Fish. In Aquaculture Nutrition; Wiley: Hoboken, NJ, USA, 2014; pp. 185-222.

22. Li, X.; Ringø, E.; Hoseinifar, S.H.; Lauzon, H.L.; Birkbeck, H.; Yang, D. The Adherence and Colonization of Microorganisms in Fish Gastrointestinal Tract. Rev. Aquac. 2019, 11, 603-618. [CrossRef]

23. Ringø, E.; Doan, H.V.; Lee, S.; Song, S.K. Lactic Acid Bacteria in Shellfish: Possibilities and Challenges. Rev. Fish. Sci. Aquac. 2020, 28, 139-169. [CrossRef]

24. Piccolo, G.; Bovera, F.; Lombardi, P.; Mastellone, V.; Nizza, S.; Di Meo, C.; Marono, S.; Nizza, A. Effect of Lactobacillus Plantarum on Growth Performance and Hematological Traits of European Sea Bass (Dicentrarchus Labrax). Aquac. Int. 2015, 23, 1025-1032. [CrossRef]

25. Dash, G.; Raman, R.P.; Pani Prasad, K.; Makesh, M.; Pradeep, M.A.; Sen, S. Evaluation of Paraprobiotic Applicability of Lactobacillus Plantarum in Improving the Immune Response and Disease Protection in Giant Freshwater Prawn, Macrobrachium Rosenbergii (de Man, 1879). Fish Shellfish Immunol. 2015, 43, 167-174. [CrossRef] [PubMed]

26. Wang, L.; Zhou, H.; He, R.; Xu, W.; Mai, K.; He, G. Effects of Soybean Meal Fermentation by Lactobacillus Plantarum P8 on Growth, Immune Responses, and Intestinal Morphology in Juvenile Turbot (Scophthalmus Maximus L.). Aquaculture 2016, 464, 87-94. [CrossRef]

27. Van Nguyen, N.; Onoda, S.; Van Khanh, T.; Hai, P.D.; Trung, N.T.; Hoang, L.; Koshio, S. Evaluation of Dietary Heat-Killed Lactobacillus Plantarum Strain L-137 Supplementation on Growth Performance, Immunity and Stress Resistance of Nile Tilapia (Oreochromis Niloticus). Aquaculture 2019, 498, 371-379. [CrossRef]

28. Siezen, R.J.; Tzeneva, V.A.; Castioni, A.; Wels, M.; Phan, H.T.; Rademaker, J.L.; Starrenburg, M.J.; Kleerebezem, M.; Molenaar, D.; van Hylckama Vlieg, J.E. Phenotypic and Genomic Diversity of Lactobacillus Plantarum Strains Isolated from Various Environmental Niches. Environ. Microbiol. 2010, 12, 758-773. [CrossRef] [PubMed]

29. Iorizzo, M.; Pannella, G.; Lombardi, S.J.; Ganassi, S.; Testa, B.; Succi, M.; Sorrentino, E.; Petrarca, S.; De Cristofaro, A.; Coppola, R. Inter-and Intra-Species Diversity of Lactic Acid Bacteria in Apis Mellifera Ligustica Colonies. Microorganisms 2020, 8, 1578. [CrossRef]

30. Iorizzo, M.; Albanese, G.; Testa, B.; Ianiro, M.; Letizia, F.; Succi, M.; Tremonte, P.; D’Andrea, M.; Iaffaldano, N.; Coppola, R. Presence of Lactic Acid Bacteria in the Intestinal Tract of the Mediterranean Trout (Salmo Macrostigma) in Its Natural Environment. Life 2021, 11, 667. [CrossRef]

31. Ruiz, L.; Margolles, A.; Sánchez, B. Bile Resistance Mechanisms in Lactobacillus and Bifidobacterium. Front. Microbiol. 2013, 4, 396. [CrossRef]

32. Wang, C.; Cui, Y.; Qu, X. Mechanisms and Improvement of Acid Resistance in Lactic Acid Bacteria. Arch. Microbiol. 2018, 200, 195-201. [CrossRef]

33. Chang, M.-H.; Hong, S.-F.; Chen, J.-H.; Lin, M.-F.; Chen, C.-S.; Wang, S.-C. Antibacterial Activity Lactobacillus Plantarum Isolated from Fermented Vegetables and Investigation of the Plantaricin Genes. Afr. J. Microbiol. Res. 2016, 10, $796-803$.

34. Yadav, R.; Puniya, A.K.; Shukla, P. Probiotic Properties of Lactobacillus Plantarum RYPR1 from an Indigenous Fermented Beverage Raabadi. Front. Microbiol. 2016, 7, 1683. [CrossRef]

35. Tremonte, P.; Pannella, G.; Succi, M.; Tipaldi, L.; Sturchio, M.; Coppola, R.; Luongo, D.; Sorrentino, E. Antimicrobial Activity of Lactobacillus Plantarum Strains Isolated from Different Environments: A Preliminary Study. Int. Food Res. J. $2017,24,852$.

36. Kaktcham, P.M.; Temgoua, J.-B.; Zambou, F.N.; Diaz-Ruiz, G.; Wacher, C.; de Lourdes Pérez-Chabela, M. In Vitro Evaluation of the Probiotic and Safety Properties of Bacteriocinogenic and Non-Bacteriocinogenic Lactic Acid Bacteria from the Intestines of Nile Tilapia and Common Carp for Their Use as Probiotics in Aquaculture. Probiotics Antimicrob. Proteins 2018, 10, 98-109. [CrossRef] [PubMed]

37. Kazuń, B.; Kazuń, K.; Żylińska, J.; Siwicki, A.K. In Vitro Study of Lactobacillus Plantarum Properties as a Potential Probiotic Strain and an Alternative Method to Antibiotic Treatment of Fish. Fish. Aquat. Life 2018, 26, 47-55. [CrossRef]

38. Foysal, M.J.; Fotedar, R.; Siddik, M.A.; Tay, A. Lactobacillus Acidophilus and L. Plantarum Improve Health Status, Modulate Gut Microbiota and Innate Immune Response of Marron (Cherax Cainii). Sci. Rep. 2020, 10, 5916. [CrossRef] [PubMed]

39. Mohamad, N.; Manan, H.; Sallehhuddin, M.; Musa, N.; Ikhwanuddin, M. Screening of Lactic Acid Bacteria Isolated from Giant Freshwater Prawn (Macrobrachium Rosenbergii) as Potential Probiotics. Aquac. Rep. 2020, 18, 100523. [CrossRef]

40. Maji, U.; Mohanty, S. Genotypic Characterization of Lactic Acid Bacteria in Gut Microbiome of Freshwater Fish. Microbiology 2017, 86, 276-285. [CrossRef] 
41. Kumaree, K.K.; Akbar, A.; Anal, A.K. Bioencapsulation and Application of Lactobacillus Plantarum Isolated from Catfish Gut as an Antimicrobial Agent and Additive in Fish Feed Pellets. Ann. Microbiol. 2015, 65, 1439-1445. [CrossRef]

42. Bucio Galindo, A.; Hartemink, R.; Schrama, J.; Verreth, J.; Bucio, G.L.; Zwietering, M. Kinetics of Lactobacillus Plantarum 44a in the Faeces of Tilapia (Oreochromis Niloticus) after Its Intake in Feed. J. Appl. Microbiol. 2009, 107, 1967-1975. [CrossRef]

43. Nathanailides, C.; Kolygas, M.; Choremi, K.; Mavraganis, T.; Gouva, E.; Vidalis, K.; Athanassopoulou, F. Probiotics Have the Potential to Significantly Mitigate the Environmental Impact of Freshwater Fish Farms. Fishes 2021, 6, 76. [CrossRef]

44. Kaewchomphunuch, T.; Charoenpichitnunt, T.; Thongbaiyai, V.; Ngamwongsatit, N.; Kaeoket, K. Cell-Free Culture Supernatants of Lactobacillus Spp. and Pediococcus Spp. Inhibit Growth of Pathogenic Escherichia Coli Isolated from Pigs in Thailand. BMC Vet. Res. 2022, 18, 60. [CrossRef]

45. Zapata, A.; Ramirez-Arcos, S. A Comparative Study of McFarland Turbidity Standards and the Densimat Photometer to Determine Bacterial Cell Density. Curr. Microbiol. 2015, 70, 907-909. [CrossRef] [PubMed]

46. Kariyawasam, K.M.G.M.M.; Yang, S.J.; Lee, N.-K.; Paik, H.-D. Probiotic Properties of Lactobacillus Brevis KU200019 and Synergistic Activity with Fructooligosaccharides in Antagonistic Activity against Foodborne Pathogens. Food Sci. Anim. Resour. 2020, 40, 297. [CrossRef] [PubMed]

47. Iorizzo, M.; Testa, B.; Lombardi, S.J.; Ganassi, S.; Ianiro, M.; Letizia, F.; Succi, M.; Tremonte, P.; Vergalito, F.; Cozzolino, A Antimicrobial Activity against Paenibacillus Larvae and Functional Properties of Lactiplantibacillus Plantarum Strains: Potential Benefits for Honeybee Health. Antibiotics 2020, 9, 442. [CrossRef] [PubMed]

48. Di Martino, C.; Testa, B.; Letizia, F.; Iorizzo, M.; Lombardi, S.J.; Ianiro, M.; Di Renzo, M.; Strollo, D.; Coppola, R. Effect of Exogenous Proline on the Ethanolic Tolerance and Malolactic Performance of Oenococcus Oeni. J. Food Sci. Technol. 2020, 57, 3973-3979. [CrossRef] [PubMed]

49. Re, R.; Pellegrini, N.; Proteggente, A.; Pannala, A.; Yang, M.; Rice-Evans, C. Antioxidant Activity Applying an Improved ABTS Radical Cation Decolorization Assay. Free Radic. Biol. Med. 1999, 26, 1231-1237. [CrossRef]

50. Aarti, C.; Khusro, A.; Varghese, R.; Arasu, M.V.; Agastian, P.; Al-Dhabi, N.A.; Ilavenil, S.; Choi, K.C. In Vitro Studies on Probiotic and Antioxidant Properties of Lactobacillus Brevis Strain LAP2 Isolated from Hentak, a Fermented Fish Product of North-East India. LWT 2017, 86, 438-446. [CrossRef]

51. Austin, B.; Austin, D.A. Bacterial Fish Pathogens: Disease of Farmed and Wild Fish; Springer: Berlin/Heidelberg, Germany, 2007; Volume 26.

52. Wuertz, S.; Schroeder, A.; Wanka, K.M. Probiotics in Fish Nutrition-Long-Standing Household Remedy or Native Nutraceuticals? Water 2021, 13, 1348. [CrossRef]

53. Novoslavskij, A.; Terentjeva, M.; Eizenberga, I.; Valcina, O.; Bartkevičs, V.; Bērzinšs, A. Major Foodborne Pathogens in Fish and Fish Products: A Review. Ann. Microbiol. 2016, 66, 1-15. [CrossRef]

54. Tripathy, S.; Kumar, N.; Mohanty, S.; Samanta, M.; Mandal, R.; Maiti, N. Characterisation of Pseudomonas Aeruginosa Isolated from Freshwater Culture Systems. Microbiol. Res. 2007, 162, 391-396. [CrossRef]

55. Arfatahery, N.; Mirshafiey, A.; Abedimohtasab, T.P.; Zeinolabedinizamani, M. Study of the Prevalence of Staphylococcus Aureus in Marine and Farmed Shrimps in Iran Aiming the Future Development of a Prophylactic Vaccine. Procedia Vaccinol. 2015, 9 , 44-49. [CrossRef]

56. Austin, B.; Stobie, M.; Robertson, P. Citrobacter Freundii: The Cause of Gastro-Enteritis Leading to Progressive Low Level Mortalities in Farmed Rainbow Trout, Oncorhynchus Mykiss Walbaum, in Scotland. Bull. Eur. Assoc. Fish Pathol. UK 1992, 12, $166-167$.

57. Muñoz-Atienza, E.; Gómez-Sala, B.; Araújo, C.; Campanero, C.; del Campo, R.; Hernández, P.E.; Herranz, C.; Cintas, L.M Antimicrobial Activity, Antibiotic Susceptibility and Virulence Factors of Lactic Acid Bacteria of Aquatic Origin Intended for Use as Probiotics in Aquaculture. BMC Microbiol. 2013, 13, 15. [CrossRef] [PubMed]

58. Danilova, T.; Adzhieva, A.; Danilina, G.; Polyakov, N.; Soloviev, A.; Zhukhovitsky, V. Antimicrobial Activity of Supernatant of Lactobacillus Plantarum against Pathogenic Microorganisms. Bull. Exp. Biol. Med. 2019, 167, 751-754. [CrossRef] [PubMed]

59. Defoirdt, T.; Sorgeloos, P.; Bossier, P. Alternatives to Antibiotics for the Control of Bacterial Disease in Aquaculture. Curr. Opin. Microbiol. 2011, 14, 251-258. [CrossRef]

60. Sharifuzzaman, S.; Austin, B. Probiotics for Disease Control in Aquaculture. Front. Microbiol. 2017, 189-222. [CrossRef]

61. Martínez-Álvarez, R.M.; Morales, A.E.; Sanz, A. Antioxidant Defenses in Fish: Biotic and Abiotic Factors. Rev. Fish Biol. Fish 2005, 15, 75-88. [CrossRef]

62. Wilhelm Filho, D. Reactive Oxygen Species, Antioxidants and Fish Mitochondria. Front Biosci. 2007, 12, 1229-1237. [CrossRef]

63. Hoseinifar, S.H.; Yousefi, S.; Van Doan, H.; Ashouri, G.; Gioacchini, G.; Maradonna, F.; Carnevali, O. Oxidative Stress and Antioxidant Defense in Fish: The Implications of Probiotic, Prebiotic, and Synbiotics. Rev. Fish. Sci. Aquac. 2021, $29,198-217$. [CrossRef]

64. Chowdhury, S.; Saikia, S. Oxidative Stress in Fish: A Review. J. Sci. Res. 2020, 12, 145-160. [CrossRef]

65. Lushchak, V.I. Environmentally Induced Oxidative Stress in Aquatic Animals. Aquat. Toxicol. 2011, 101, 13-30. [CrossRef]

66. Mishra, V.; Shah, C.; Mokashe, N.; Chavan, R.; Yadav, H.; Prajapati, J. Probiotics as Potential Antioxidants: A Systematic Review. J. Agric. Food Chem. 2015, 63, 3615-3626. [CrossRef] [PubMed]

67. Dawood, M.A.; Koshio, S.; Esteban, M.Á. Beneficial Roles of Feed Additives as Immunostimulants in Aquaculture: A Review. Rev. Aquac. 2018, 10, 950-974. [CrossRef] 
68. Van Doan, H.; Hoseinifar, S.H.; Ringø, E.; Ángeles Esteban, M.; Dadar, M.; Dawood, M.A.; Faggio, C. Host-Associated Probiotics: A Key Factor in Sustainable Aquaculture. Rev. Fish. Sci. Aquac. 2020, 28, 16-42. [CrossRef]

69. Feng, T.; Wang, J. Oxidative Stress Tolerance and Antioxidant Capacity of Lactic Acid Bacteria as Probiotic: A Systematic Review. Gut Microbes 2020, 12, 1801944. [CrossRef] [PubMed]

70. Prior, R.L.; Wu, X.; Schaich, K. Standardized Methods for the Determination of Antioxidant Capacity and Phenolics in Foods and Dietary Supplements. J. Agric. Food Chem. 2005, 53, 4290-4302. [CrossRef]

71. Kedare, S.B.; Singh, R.P. Genesis and Development of DPPH Method of Antioxidant Assay. J. Food Sci. Technol. 2011, 48, 412-422. [CrossRef]

72. Chanput, W.; Krueyos, N.; Ritthiruangdej, P. Anti-Oxidative Assays as Markers for Anti-Inflammatory Activity of Flavonoids. Int Immunopharmacol. 2016, 40, 170-175. [CrossRef]

73. Arnao, M.B.; Cano, A.; Acosta, M. The Hydrophilic and Lipophilic Contribution to Total Antioxidant Activity. Food Chem. 2001, 73, 239-244. [CrossRef]

74. Izuddin, W.I.; Humam, A.M.; Loh, T.C.; Foo, H.L.; Samsudin, A.A. Dietary Postbiotic Lactobacillus Plantarum Improves Serum and Ruminal Antioxidant Activity and Upregulates Hepatic Antioxidant Enzymes and Ruminal Barrier Function in Post-Weaning Lambs. Antioxidants 2020, 9, 250. [CrossRef]

75. Tang, W.; Li, C.; He, Z.; Pan, F.; Pan, S.; Wang, Y. Probiotic Properties and Cellular Antioxidant Activity of Lactobacillus Plantarum MA2 Isolated from Tibetan Kefir Grains. Probiotics Antimicrob. Proteins 2018, 10, 523-533. [CrossRef]

76. Li, S.; Zhao, Y.; Zhang, L.; Zhang, X.; Huang, L.; Li, D.; Niu, C.; Yang, Z.; Wang, Q. Antioxidant Activity of Lactobacillus Plantarum Strains Isolated from Traditional Chinese Fermented Foods. Food Chem. 2012, 135, 1914-1919. [CrossRef] [PubMed]

77. Das, D.; Goyal, A. Antioxidant Activity and $\gamma$-Aminobutyric Acid (GABA) Producing Ability of Probiotic Lactobacillus Plantarum DM5 Isolated from Marcha of Sikkim. LWT-Food Sci. Technol. 2015, 61, 263-268. [CrossRef]

78. Grajek, K.; Sip, A.; Foksowicz-Flaczyk, J.; Dobrowolska, A.; Wita, A. Adhesive and Hydrophobic Properties of the Selected LAB Isolated from Gastrointestinal Tract of Farming Animals. Acta Biochim. Pol. 2016, 63, 311-314. [CrossRef] [PubMed]

79. Kos, B.; Šušković, J.; Vuković, S.; Šimpraga, M.; Frece, J.; Matošić, S. Adhesion and Aggregation Ability of Probiotic Strain Lactobacillus Acidophilus M92. J. Appl. Microbiol. 2003, 94, 981-987. [CrossRef]

80. Darmastuti, A.; Hasan, P.N.; Wikandari, R.; Utami, T.; Rahayu, E.S.; Suroto, D.A. Adhesion Properties of Lactobacillus Plantarum Dad-13 and Lactobacillus Plantarum Mut-7 on Sprague Dawley Rat Intestine. Microorganisms 2021, 9, 2336. [CrossRef]

81. Saboktakin-Rizi, M.; Behbahani, B.A.; Hojjati, M.; Noshad, M. Identification of Lactobacillus Plantarum TW29-1 Isolated from Iranian Fermented Cereal-Dairy Product (Yellow Zabol Kashk): Probiotic Characteristics, Antimicrobial Activity and Safety Evaluation. J. Food Meas. Charact. 2021, 15, 2615-2624. [CrossRef]

82. Bucio, A.; Hartemink, R.; Schrama, J.W.; Verreth, J.; Rombouts, F.M. Survival of Lactobacillus Plantarum 44a after Spraying and Drying in Feed and during Exposure to Gastrointestinal Tract Fluids in Vitro. J. Gen. Appl. Microbiol. 2005, 51, 221-227. [CrossRef]

83. He, E.; Wurtsbaugh, W.A. An Empirical Model of Gastric Evacuation Rates for Fish and an Analysis of Digestion in Piscivorous Brown Trout. Trans. Am. Fish. Soc. 1993, 122, 717-730. [CrossRef]

84. Handeland, S.O.; Imsland, A.K.; Stefansson, S.O. The Effect of Temperature and Fish Size on Growth, Feed Intake, Food Conversion Efficiency and Stomach Evacuation Rate of Atlantic Salmon Post-Smolts. Aquaculture 2008, 283, 36-42. [CrossRef]

85. Miegel, R.P.; Pain, S.J.; van Wettere, W.H.E.J.; Howarth, G.S.; Stone, D.A.J. Effect of Water Temperature on Gut Transit Time, Digestive Enzyme Activity and Nutrient Digestibility in Yellowtail Kingfish (Seriola Lalandi). Aquaculture 2010, 308, 145-151. [CrossRef]

86. Volkoff, H.; Rønnestad, I. Effects of Temperature on Feeding and Digestive Processes in Fish. Temperature 2020, 7, 307-320. [CrossRef] [PubMed]

87. Little, A.G.; Loughland, I.; Seebacher, F. What Do Warming Waters Mean for Fish Physiology and Fisheries? J. Fish Biol. 2020, 97, 328-340. [CrossRef] [PubMed]

88. Siezen, R.J.; van Hylckama Vlieg, J.E. Genomic Diversity and Versatility of Lactobacillus Plantarum, a Natural Metabolic Engineer. Microb. Cell Factories 2011, 10, S3. [CrossRef] [PubMed]

89. Jain, K.E.; Farrell, A.P. Influence of Seasonal Temperature on the Repeat Swimming Performance of Rainbow Trout Oncorhynchus Mykiss. J. Exp. Biol. 2003, 206, 3569-3579. [CrossRef]

90. López-Olmeda, J.; Sánchez-Vázquez, F. Thermal Biology of Zebrafish (Danio Rerio). J. Therm. Biol. 2011, 36, 91-104. [CrossRef] 